\title{
Planetary demands
}

Citation for published version (APA):

Hummels, H., \& Argyrou, A. (2021). Planetary demands: Redefining sustainable development and sustainable entrepreneurship. Journal of Cleaner Production, 278, [123804]. https://doi.org/10.1016/j.jclepro.2020.123804

Document status and date:

Published: 01/01/2021

DOI:

10.1016/j.jclepro.2020.123804

Document Version:

Publisher's PDF, also known as Version of record

\section{Document license:}

Taverne

\section{Please check the document version of this publication:}

- A submitted manuscript is the version of the article upon submission and before peer-review. There can be important differences between the submitted version and the official published version of record.

People interested in the research are advised to contact the author for the final version of the publication, or visit the DOI to the publisher's website.

- The final author version and the galley proof are versions of the publication after peer review.

- The final published version features the final layout of the paper including the volume, issue and page numbers.

Link to publication

\footnotetext{
General rights rights.

- You may freely distribute the URL identifying the publication in the public portal. please follow below link for the End User Agreement:

www.umlib.nl/taverne-license

Take down policy

If you believe that this document breaches copyright please contact us at:

repository@maastrichtuniversity.nl

providing details and we will investigate your claim.
}

Copyright and moral rights for the publications made accessible in the public portal are retained by the authors and/or other copyright owners and it is a condition of accessing publications that users recognise and abide by the legal requirements associated with these

- Users may download and print one copy of any publication from the public portal for the purpose of private study or research.

- You may not further distribute the material or use it for any profit-making activity or commercial gain

If the publication is distributed under the terms of Article $25 \mathrm{fa}$ of the Dutch Copyright Act, indicated by the "Taverne" license above, 


\title{
Planetary demands: Redefining sustainable development and sustainable entrepreneurship
}

\author{
Harry Hummels ${ }^{a, b},{ }^{*}$, Aikaterini Argyrou ${ }^{c}$ \\ a School of Business and Economics, Finance Department, Maastricht University, PO Box 616, 6200, MD, Maastricht, The Netherlands \\ ${ }^{\mathrm{b}}$ Utrecht School of Economics, Entrepreneurship Department, Utrecht University, P.O. Box 80125, 3508, TC, Utrecht, The Netherlands \\ ${ }^{\mathrm{c}}$ Nyenrode Business University Center for Entrepreneurship, Governance \& Stewardship, Nyenrode Business University, Straatweg 25, 3621 BG Breukelen, \\ PO Box 130, 3620, AC, Breukelen, the Netherlands
}

\section{A R T I C L E I N F O}

\section{Article history:}

Received 14 February 2020

Received in revised form

20 June 2020

Accepted 14 August 2020

Available online 22 August 2020

\section{Keywords:}

Sustainable development

Sustainable entrepreneurship

Planetary boundaries

Externalities Brundtland Commission

Interface

\begin{abstract}
A B S T R A C T
In 1987, the World Commission on Environment and Development (WECD) provided a seminal definition of sustainable development, which has become the landmark for countless governments, businesses and civil society organizations to contribute to a sustainable world. And yet, it is precisely the nuanced approach of the WECD - focusing simultaneously on the protection of nature, the creation of economic welfare, and social inclusion that threatens the boundaries of the Earth system. Governments and enterprises fail to respect the planetary boundaries. Hence, they compromise the ability of future generations to meet their needs. Their focus on economic value creation for present generations ignores to a large extent the potential consequences for generations to come and creates a 'tragedy of the commons'. As a result, many enterprises unjustifiably picture themselves as contributing to sustainable development. This calls for a revised definition of sustainable development that allows for the pursuit of economic growth but requires compliance with the planetary boundaries. A potential way out of the tragedy is offered by sustainable entrepreneurship that promotes economic growth while intends to overcome sustainability related challenges through the creation and distribution of solutions. However, sustainable entrepreneurs and enterprises should be more explicit about their contribution to the transgression of the planetary boundaries along the lines of a more strictly defined concept of sustainable development. An example of a leading company is provided that operationalizes sustainable development in a way to not transgress these boundaries.
\end{abstract}

(c) 2020 Elsevier Ltd. All rights reserved.

\section{Introduction}

${ }^{1}$ The world today is not sustainable, not resilient and not fair for the majority of mankind. Human activity, and more in particular economic activity, pushes the planet beyond its natural boundaries. Some of the most significant challenges to what Reid et al. (2010) have called the 'Earth system', ${ }^{2}$ relate to its planetary boundaries

\footnotetext{
* Corresponding author.

E-mail addresses: h.hummels@maastrichtuniversity.nl (H. Hummels), a argyrou2@nyenrode.nl (A. Argyrou).

1 The authors would like to thank the journal's anonymous reviewers for their excellent comments on a previous version of the article. The quality of our work has benefitted from their feedback.

2 Reid et al. (2010, p. 917) define the 'Earth system' as “the physical, chemical, biological, and social components, processes, and interactions that together determine the state and dynamics of Earth, including its biota and human occupants".
}

(Rockström et al., 2009a, 2009b; Steffen et al., 2015) and its human carrying capacity (Brown et al., 1987; Ehrlich, 1968). More in particular the challenges include, inter alia, excessive air and water pollution, deforestation, natural resource scarcity, climate change, overpopulation, migration, massive poverty, social inequality, discrimination, and the consequences of war including terrorism. These challenges to the climate and the natural environment have been the result of only a few centuries of industrial economic development, with limited attention for environmental and social externalities. Except for a scarce antecedent contribution (Malthus, 1826), it was only since the publication of Rachel Carson's Silent Spring in 1962, Paul Ehrlich's The population bomb in 1968, and the Club of Rome's The limits to growth in 1972, that governments, corporations, non-governmental organizations (NGOs) and academics have gradually come to understand the limitations of the once presumed limitless and never ending strive for (economic) progress. Science and technology demonstrate that the 
consequences of the existing economic, social and environmental challenges become threatening to the (human) existence on this planet and to Earth as we know it (Lovelock and Margulis, 1974; Rockström et al., 2009a, 2009b). Acknowledging the Earth's decline, respecting its planetary boundaries is more imperative than ever before (Salmivaara and Kibler, 2020). At the heart of 'sustainable development' in the way conceived by the World Commission on Environment and Development (WCED), is the belief that economic prosperity, human development and environmental protection are interrelated. In a world faced with environmental degradation, inequality, injustice, poverty, and a lack of development opportunities for people, economic growth is a sine qua non. Although it may be true, as the WCED argues, that respect for the environment depends on economic growth and human progress, the ways in which previous and current societies have implemented the agenda for development is full of conflicting interests that potentially threaten life on Earth. Society is confronted with "parallel discourses" (Redclift, 2005) on economic growth, social development, and environmental protection (cf. Daly, 2007), resulting in a potential clash between the interests and needs of the present generations and the ability of future generations to meet their needs (WCED, 1987; Mebratu, 1998). One way to overcome the potential dichotomy between present and future generations and the tension between the discourses, is provided by 'sustainable entrepreneurship'. Dean and McMullen (2007, p. 58) define sustainable entrepreneurship as: "the process of discovering, evaluating, and exploiting economic opportunities that are present in market failures which detract from sustainability, including those that are environmentally relevant". There is a positive undertone in this type of entrepreneurship that can potentially help to address the environmental decline of the planet while respecting the planetary boundaries. Increasingly, enterprises ranging from small startups to multinationals claim to contribute to a more sustainable future. A case in point is provided by the American Business Roundtable (2019). In its restatement of the purpose of the corporation, the Roundtable commits to respecting the people in our communities and protecting the environment "by embracing sustainable practices across our businesses" (American Business Roundtable, 2019). When markets increasingly offer opportunities for producing and selling environmentally friendly products and services, which are widely adopted by previously unrestrained advocates of shareholder capitalism, society may be looking at the emperor's new clothes. Even though sustainable entrepreneurship can make a significant contribution in improving environmental sustainability while running a profitable business (cf. Davies and Chambers, 2018; Dean and McMullen, 2007; Gast et al., 2017; Horne et al., 2020; Pinkse and Groot, 2015; Teran-Yepez et al., 2020), numerous enterprises fail to balance the needs of present and future generations by insufficiently respecting the planetary boundaries. This partly has to do with the lack of clarity in the definition of the WCED, which does not set strict limits to environmental degradation. In order to overcome this lack of clarity, we will critically assess the concept of sustainable development and describe how it is being used in the sustainable entrepreneurship literature. This will be followed by an analysis of sustainable entrepreneurship's potential to address "market failures which detract from sustainability" (Dean and McMullen, 2007, p. 58) while respecting the planetary boundaries. As a result, we propose a stricter definition of 'sustainable development' than that of the WCED.

\section{The concept of sustainable development}

From 1983 to 1987, the WCED- also known and referred to in this article interchangeably as the 'Brundtland Commission' - investigated the environmental, social, and governance challenges that global society faced in the 1980s (WCED, 1987). Human and ecological survival was tightly coupled to uneven development, population growth and increasing poverty. "They all place unprecedented pressures on the planet's lands, waters, forests, and other natural resources, not least in the developing countries" (WCED, 1987, p. 14). In its report, Our Common Future, the Brundtland Commission outlined new opportunities for economic growth, based on policies that sustain and expand the environmental resource base (WCED, 1987). Growth is "absolutely essential to relieve the great poverty that is deepening in much of the developing world" (WCED, 1987, p. 18). To accommodate the needs of the developing world, the Brundtland Commission introduced the concept of 'sustainable development' as a development that: "meets the needs of the present without compromising the ability of future generations to meet their own needs" (WCED, 1987, p. 24).

Obviously, this formula is vague and the Brundtland Commission is aware of the elusiveness of the concept, when it acknowledges that "sustainable development is not a fixed state of harmony, but rather a process of change in which the exploitation of resources, the direction of investments, the orientation of technological development, and institutional change are made consistent with future as well as present needs" (WCED, 1987, p. 25). What makes sustainable development such a challenging concept, is the interrelatedness between economic prosperity, human development and environmental protection. Poverty, for instance, negatively impacts sustainable development, according to the Brundtland Commission (WCED, 1987). A world in which poverty is endemic will continue to provide ecological challenges on a global scale that push the boundaries of life on this planet. It is for this reason that the Brundtland Commission calls upon government for "a return to multilateralism" and "cooperation" (WCED, 1987, p. 12) to overcome poverty, while acknowledging that "at a minimum, sustainable development must not endanger the natural systems that support life on Earth" (WCED, 1987, p. 44). It is precisely the vagueness of the Brundtland Commission's operationalization of sustainable development, providing no guidance regarding the endangering of the natural systems, that has contributed to transgression of the planetary boundaries.

\section{How 'sustainable' is sustainable development?}

The focus on economic growth leads to the question whether sustainable development becomes an oxymoron ever since past generations have put economic growth center stage without giving too much notice to the negative externalities (cf. Daly, 2007; Lankoski, 2016; Mebratu, 1998). Over time, the moral claim of equity and sustainability in Our common future (WCED, 1987) has turned into a utilitarian outlook towards the future we have in common - or more accurately: the tragedy we have in common (Hardin, 1968). To better understand the fundamental flaw in the conceptualization of 'sustainable development' in Our Common Future we have to go back in history. When John Locke (1689) argued for adding one's labour to the commons and produce and appropriate the outcomes of this labour, he imposed two restrictions. The first deals with the limitation of production to that amount that people consume. He was the first to call for a 'no waste 
policy'. The second limitation or proviso was that production and appropriation are allowed as long as there is still enough and as good left for others. In the words of Locke (1689, p. 118): "Nobody could think himself injured by the drinking of another man, though he took a good draught, who had a whole river of the same water left him to quench his thirst. And the case of land and water, where there is enough of both, is perfectly the same." In the 17th century, production and appropriation may have respected this Lockean proviso, ${ }^{3}$ but in the 21 st century, it is mainly the developed world that continues to add livestock to the commons thereby leaving "not enough and as good" for the developing world behind - now and in the future. As Salmivaara and Kibler (2020) demonstrate, present generations endorse entrepreneurial activities presumed to contribute to sustainable development, while ignoring the possibility that entrepreneurship "potentially produce[s] negative outcomes" (Salmivaara and Kibler, 2020, p. 24).

Finding solutions to the grand environmental challenges of present times, while creating economic growth, has raised questions about the elusiveness of 'sustainable development' (Brown et al., 1987; Lankoski, 2016; Pater and Cristea, 2016; Shearman, 1990; White, 2013). What are the needs of the present and future generations? What is the relation between the limits to the environment and economic growth? Do we really need economic growth as Brundtland Commission claims, or do we need a redistribution of access to and outcomes of economic prosperity while limiting the use of natural resources? The World Bank already noticed in 1985 that sustainable economic development depends on sound environmental management (Holdren et al., 1995). According to the authors, such sustainable development requires a process or condition "that can be maintained indefinitely without progressive diminution of valued qualities inside or outside the system in which the process operates or the condition prevails" (Holdren et al., 1995, p. 3; cf. IUCN, 1991). This "dictionary definition" is not particularly helpful to guide practical decision-making (Holdren et al., 1995; Constanza and Patten, 1995). Sustainable development requires tough choices. Some of these choices come from the fact that "our planet has fundamental limits imposed by physics and biology, and we humans cannot sustain activities that go far beyond those fundamental limits. Naturally, these limits are not always immediate and absolute: we can often cross a limit for a while, but we can't stay there sustainably without risking great harm to the environment and society." (Foley, 2017, p. 251) As a result, Sachs (2004) points out, sustainable development requires making political choices. No technical solution can solve economic, social and environmental system problems (Hardin, 1968). Society is faced with what Hardin called 'the tragedy of the commons', resulting in individual appropriation of common goods and not leave behind "enough and as good" for others. Hardin pictured a common pasture in which it is rational for each herdsman to keep as many cattle as possible and maximize his utility. This strategy works well, as long as there are no limits to the commons and every herdsman can add cattle without having a negative impact on other herdsmen - either qualitatively or quantitatively. Unfortunately for the present generations, "at this point, Hardin (1968, p. 1244) writes, the inherent logic of the commons remorselessly generates tragedy".

Based on the definition of planetary boundaries (Rockström et al., 2009a, 2009b), scientist have become increasingly critical about the notion of sustainable development and argue for the need to set absolute limits. The first step to redefine sustainable development was taken by Griggs et al. (2013, p. 306). The authors described it as: "the development that meets the needs of the present while safeguarding Earth's life-support system, on which the welfare of current and future generations depends" (Griggs et al., 2014, p. 49). This definition, however, is still in need of clear demarcation lines to prevent transgression of essential environmental thresholds. As Foley (2017) argues, since we cannot break the laws of physics, society has to respect the boundaries of the "safe operating space" (Rockström et al., 2009a, 2009b; Steffen et al., 2015) and limit emissions that structurally and over a long period of time transgress these boundaries in nine critical areas: climate change, novel entities, stratospheric ozone depletion, atmospheric aerosol loading, ocean acidification, biochemical flows (nitrogen and phosphorus), freshwater use, land-system change, biosphere integrity, genetic diversity. ${ }^{4}$ The urgency of taking measures is determined by the extent and the duration with which the boundaries are exceeded. At present, this means that action is most required in areas dealing with nitrogen, phosphorus, genetic diversity (Steffen et al., 2015), and fresh water (Jaramillo and Destouni, 2015). Emissions may have gone beyond "the zone of uncertainty" in other areas as well. That means that they pose a direct threat to specific parts or regions of the Earth system and require remedy. The size and nature of this remediation are, however, a matter of "analytic deliberations" (Dietz et al., 2003; Sachs, 2004) - the process of bringing together stakeholders in a science-based process of consensus building.

Past, current and future generations are not the 'Lockean owners' of our planet. Society cannot freely decide about the production and appropriation of the outputs and outcomes of our labour without at least protecting the ability of future generations to meet their needs. As the business world - ranging from agriculture to fossil fuel exploitation and from transportation to utilities and (financial) service industries - significantly contributes to the transgression of the limits, the private sector has an important role to play in overcoming the tragedy. Increasingly, enterprises and corporations say that they take sustainable development seriously as part of their business models (Hart and Milstein, 2003; Hockerts and Wüstenhagen, 2010; York and Venkataraman, 2010). However, the question arises if and to what extent the latest insights regarding the planetary boundaries have been sufficiently reflected in the study of sustainable businesses, including sustainable entrepreneurship. As sustainable entrepreneurs are at the forefront of creating economic growth that leads to positive externalities for the planet (Liu et al., 2018; Reid et al., 2010; Walker, 2009), do they respect the boundaries and contribute to a reduction of the emissions to water, soil and air? The remainder of this article explores to what extent sustainable entrepreneurship, in its attempts to contribute to sustainable development, takes into account the idea of planetary boundaries. In the next section, we will assess the extent to which the sustainable entrepreneurship literature positions itself in explicitly assessing:

\section{- Negative externalities created through sustainable entrepre- neurial interventions; \\ - Compliance with the planetary boundaries; and}

\footnotetext{
${ }^{3}$ Locke himself, however, was already skeptical about this idea when he describes in section 35 the situation in England, "where there are many people living under a government" that "no-one can enclose or appropriate any part of any common land without the consent of all his fellow-commoners". In Locke's world, at the end of the 17th century, there was "land enough in the world to suffice twice as many people as there are" (Locke, 1689 section 36).
}

\footnotetext{
${ }^{4}$ We need to understand that these nine boundaries are mainly the result of our past production and appropriation processes. This means that the planetary boundaries do not consist of a fixed set of environmental challenges and can change over time as a result of our current and future economic taking of the commons.
} 
- Strategies to balance the constituent elements of sustainable development, being economic prosperity, environmental protection and human development.

As an illustration, Interface Inc. will be introduced as a company that actively reduces its emissions and waste and collaborates with partners to reduce the value chain's environmental footprint.

\section{The concept of sustainable entrepreneurship}

Entrepreneurs always play some role in society (Baumol, 1990, p. 894), leading to numerous innovations including, but not limited to, the introduction of a new good or service, the improvement of present goods and services, the use of new production methods, entering a new market, or carrying out the new organization of an industry by creating, for example, a monopoly (Schumpeter, 1934). According to Baumol (1990), the role of entrepreneurship in business may be significant, but is not always productive. It sometimes includes activities of questionable value to society, such as emitting greenhouse gasses and contributing to global warming. Entrepreneurship, as the pursuit of opportunities (Stevenson et al., 1989) beyond the resources controlled by the entrepreneur (Eisenmann, 2013), should therefore be scrutinized for the creation of positive and negative (environmental) outputs and outcomes.

Entrepreneurship and entrepreneurship research particularly regard the understanding of the discovery, exploitation and creation of entrepreneurial opportunities (Carter, 2006; Dean and McMullen, 2007; Venkataraman, 1997). Entrepreneurs depend on business opportunities to seek value-creation. Such opportunities might exist due to "the partitioning of knowledge among individuals" which do not possess the same information concerning the market economy and/or market failures (Venkataraman, 1997, p. 122). Influencing factors are, among others, "information asymmetry and prior knowledge", "social networks", "the entrepreneur' personality traits" and/or "type of opportunity" (Ardichvili et al., 2003, p. 106). Under an effectuation logic and in complex situations the entrepreneurial process might regard the "creation of the opportunity" apart from opportunity discovery and identification (Sarasvathy, 2001, p. 249). However, several obstacles prohibit opportunity exploitation, identification and discovery (Dean and McMullen, 2007). These obstacles can be inherent in market failures (Dean and McMullen, 2007, p. 61), inhibiting the efficient functioning of the market. Often, there are externalities, i.e. costs or benefits of transactions on third parties other than those involved in the transaction itself without their knowledge or permission (Dean and McMullen, 2007; Santos, 2012). Depending on their beneficial or damaging effect to third parties, externalities are divided into positive and/or negative (Cohen and Winn, 2007; Dean and McMullen, 2007; Santos, 2012). A negative externality is, for instance, the cost of environmental pollution due to industrial activity; whereas an example of a positive externality is the value of individual education improved skills and knowledge used for the welfare of society. Negative externalities allow the individual benefit (e.g. earned by industrial activity) to exceed the collective benefit (e.g. enjoying a clean environment) of society. Positive externalities allow the collective benefit (e.g. welfare) of society to exceed the individual benefit (e.g. education).

The market neglects negative externalities and fails to ensure the sustainability of natural assets, as Dean and McMullen (2007, pp. 55-56) argue. It diminishes the Earth's ability to provide for future generations. Traditionally and as a result of market imperfections, Hockerts and Wüstenhagen (2010) point out, environmental scientists and economists have called for a limit to growth (Meadows et al., 1972) and a steady state economy (Daly, 1973). Economic progress should be "in equilibrium with basic ecological support systems" (Strivers, 1976, quoted in Hockerts and Wüstenhagen, 2010, p. 484). Others, like Santos (2012), refer to the removal of (negative) externalities as an important government responsibility. By developing institutional mechanisms, i.e. "regulation", "taxation" and/or "market"' mechanisms governments influence corporate decision-making and contribute to discouraging negative externalities or encouraging positive externalities (Santos, 2012, p. 341). The responsibility to remove or overcome negative externalities, though, is not restricted to governments only. Market players or influencers like businesses - including sustainable entrepreneurs -, multilateral organizations, consumers, civil society organizations, and academics have a responsibility as well. A process of change and societal transformation can be positively impacted through private organizations, i.e. entrepreneurs "who establish or modify institutions to reduce transaction costs" (Dean and McMullen, 2007, p. 62). In doing so, they are motivated by market failures that lead to environmental degradation and "provide entrepreneurial opportunities whose exploitation promises profit and improvements in social welfare" (Dean and McMullen, 2007, p. 58). Entrepreneurship is therefore believed to simultaneously provide for institutional change and societal transformation (Santos, 2012; Stål and Bonnedahl, 2016; Salmivaara and Kibler, 2020).

Noticing the importance of balancing the demands of the economy and the ecological support systems, the question arises what should be sustained through entrepreneurship and what can be developed. Shepherd and Patzelt (2011, p. 149) examine particularly "the mechanism of inducing change" based on "what is sustained and what is developed?" in sustainable entrepreneurship. The authors examine what is to be sustained, i.e. environment-friendly institutions, community-based institutions, and institutional trade-offs. They also examine what is to be developed, i.e.: economic benefits, and non-economic gains for others (Shepherd and Patzelt, 2011, p. 151). The question is, however, whether and to what extent the core elements that we presented in the previous section (i.e., ex-ante assessment of negative externalities, complying with the planetary boundaries and balancing economic growth, environmental protection and human development) are reflected in the wide range of definitions of sustainable entrepreneurship. An overview of scholarly approaches towards sustainable entrepreneurship can be found in Table 1. This table is based on research by Muñoz and Cohen (2018, p. 306) and complemented with additional definitions published in the years of 2014-2019.

\section{Sustainable entrepreneurship and the planetary boundaries}

The definitions of sustainable entrepreneurship in the previous section have in common that they focus on economic value creation and economic development, while simultaneously creating positive social and environmental outcomes. Sustainable entrepreneurship is perceived as a contribution to solving environmental problems and achieving environmental protection (Cohen and Winn, 2007; Dean and McMullen, 2007), while sizing business opportunities in parallel (Thompson et al., 2011). With the rise of awareness among sustainable entrepreneurs and within sustainable enterprises and their spotting of opportunities for innovation, it is expected that market failures will diminish (Cohen and Winn, 2007; Hockerts and Wüstenhagen, 2010). Entrepreneurship is seen as "the engine of sustainable development", expecting that its innovative power "will bring about the next industrial revolution and a more sustainable future" (Pacheco et al., 2010, p. 464). This development takes place in societies that call for a "sustainability transformation of industry", leading enterprises to internalize costs that were 
Table 1

Scholarly definitions of the sustainable entrepreneurship concept.

\begin{tabular}{|c|c|}
\hline Authors & Definition \\
\hline Crals and Vereeck (2004) & $\begin{array}{l}\text { Sustainable entrepreneurship is the continuing commitment by business to behave ethically and contribute to economic development while } \\
\text { improving the quality of life of the workforce, their families, local communities, the society and the world at large as well as future } \\
\text { generations }\end{array}$ \\
\hline Cohen and Winn (2007) & $\begin{array}{l}\text { Sustainable entrepreneurship as the examination of how opportunities to bring into existence future goods and services are discovered, } \\
\text { created and exploited, by whom and with what economic, psychological, social and environmental consequences. }\end{array}$ \\
\hline Dean and McMullen (2007) & $\begin{array}{l}\text { Sustainable entrepreneurship is the process of discovering, evaluating and exploiting economic opportunities that are present in market } \\
\text { failures, which detract from sustainability, including those that are environmentally relevant. }\end{array}$ \\
\hline $\begin{array}{l}\text { Katsikis and } \\
\quad \text { Kyrgidou (2007) }\end{array}$ & $\begin{array}{l}\text { Sustainable entrepreneurship is the teleological process aiming at the achievement of sustainable development, by discovering, evaluating } \\
\text { and exploiting opportunities and creating value that produces economic prosperity, social cohesion and environmental protection. }\end{array}$ \\
\hline Parrish and Foxon (2006) & $\begin{array}{l}\text { Sustainability-driven entrepreneurship describes those entrepreneurial activities in which the central guiding purpose is to make a } \\
\text { substantial contribution to sustainable development. More specifically, sustainability entrepreneurs design ventures with the primary } \\
\text { intention of contributing to improved environmental quality and social well-being in ways that are mutually supportive. }\end{array}$ \\
\hline Tilley and Young (2006) & $\begin{array}{l}\text { A sustainability entrepreneur is an individual who holistically integrates the goals of economic, social and environmental entrepreneurship } \\
\text { into an organization that is sustainable in its goal and sustainable in its form of wealth generation. }\end{array}$ \\
\hline O'Neill et al. (2006) & $\begin{array}{l}\text { Sustainability entrepreneurship is a process of venture creation that links the activities of entrepreneurs to the emergence of value-creating } \\
\text { enterprises that contribute to the sustainable development of the social-ecological system. }\end{array}$ \\
\hline $\begin{array}{l}\text { Hockerts and } \\
\text { Wüstenhagen (2010) }\end{array}$ & $\begin{array}{l}\text { Sustainable entrepreneurship is the discovery and exploitation of economic opportunities through the generation of market disequilibria } \\
\text { that initiate the transformation of a sector towards an environmentally and socially more sustainable state. }\end{array}$ \\
\hline Pacheco et al. (2010) & $\begin{array}{l}\text { Sustainable entrepreneurship is the discovery, creation, evaluation and exploitation of opportunities to create future goods and services that } \\
\text { is consistent with sustainable development goals. }\end{array}$ \\
\hline $\begin{array}{l}\text { Kuckertz and } \\
\text { Wagner (2010) }\end{array}$ & $\begin{array}{l}\text { Sustainable development-oriented entrepreneurs are those individuals with entrepreneurial intentions who aim to manage a triple bottom } \\
\text { line. }\end{array}$ \\
\hline Patzelt and Shepherd (2011) & $\begin{array}{l}\text { Sustainable entrepreneurship is the discovery, creation and exploitation of opportunities to create future goods and services that sustain the } \\
\text { natural and/or communal environment and provide development gain for others. }\end{array}$ \\
\hline Shepherd and Patzelt (2011) & $\begin{array}{l}\text { Sustainable entrepreneurship is focused on the preservation of nature, life support and community in the pursuit of perceived opportunities } \\
\text { to bring into existence future products, processes and services for gain, where gain is broadly construed to include economic and non- } \\
\text { economic gains to individuals, the economy and society. }\end{array}$ \\
\hline $\begin{array}{l}\text { Schaltegger and } \\
\text { Wagner (2011) }\end{array}$ & $\begin{array}{l}\text { Sustainable entrepreneurship can be described as an innovative, market-oriented and personality-driven form of creating economic and } \\
\text { societal value by means of breakthrough environmentally or socially beneficial market or institutional innovations. }\end{array}$ \\
\hline Lans et al. (2014) & $\begin{array}{l}\text { Sustainable entrepreneurship is seen as a way of generating competitive advantage by identifying sustainability as new business } \\
\text { opportunities, resulting in new and sustainable products, methods of production or ways of organizing business processes in a sustainable } \\
\text { way. }\end{array}$ \\
\hline Belz and Binder (2017) & $\begin{array}{l}\text { Sustainable entrepreneurship is the recognition, development and exploitation of opportunities by individuals to bring into existence future } \\
\text { goods and services with economic, social and ecological gains. }\end{array}$ \\
\hline
\end{tabular}

previously carried by society (Hockerts and Wüstenhagen, 2010, p. 484). ${ }^{5}$ Sustainable development, in this respect, is mainly reflected as the simultaneous improvement of economic prosperity and welfare, environmental quality and protection, social cohesion and well-being, while leaving unclear whether sustainable entrepreneurship leads to a socially just and ecologically sustainable society (Hall et al., 2010). The vague references to ecological sustainability, such as "sustainable development of the social-ecological system" (O'Neill et al., 2006 p. 34), sustaining "the natural and/or communal environment" (Patzelt and Shepherd, 2010, p. 2), preserving "nature, life support and community" (Shepherd and Patzelt, 2011, p. 137), "bring into existence future goods and services with economic, social and ecological gains" (Belz and Binder, 2017, p. 2) are, therefore, a cause of concern. Nowhere, do the definitions address the tension between potentially irreplaceable ecological support systems and the transgression of the limits to these systems. They do not call for an ex-ante assessment of the potential environmental downside of economic value creation, nor do they address the need to protect the planetary boundaries. The potential failure of the manifestations of sustainable entrepreneurship in protecting and promoting sustainable development that respects the planetary boundaries therefore requires alertness (Thompson et al., 2011) toward the consequences of the activities and behaviors of businesses, including sustainable entrepreneurs, and their impact on these boundaries.

\footnotetext{
${ }^{5}$ Internalizing costs is just one way for innovation to contribute to sustainable development. New products and services can also be designed in ways that pre-
} vious cost no longer exist.

\subsection{The contribution of sustainable entrepreneurship}

We do acknowledge the positive contribution of sustainable and environmental entrepreneurship to create a world in which the simultaneous preservation and development of the Earth system is enacted (Austin et al., 2006; Emerson, 2003; Zahra et al., 2008). This is not only achieved through the products and services designed, developed, produced, marketed and recycled by sustainable entrepreneurs, but also through political action (Dean and McMullen, 2007; Cohen and Winn, 2007; Pacheco et al., 2010; Pinkse and Groot, 2015). Through collective action sustainable entrepreneurs can influence policy makers in adopting policies that create or support sustainable development (Pacheco et al., 2010; Pinkse and Groot, 2015; Yoffie, 1988). However, these scholars point out that sustainable entrepreneurs often have to deal with market incumbents that slow down the process or even prevent progress by stalling to protect their short-term interests - even within industry associations that cautiously promote change (Pinkse and Groot, 2015, p. 647). The omission to sufficiently address the limits to economic growth becomes problematic when even leaders in the sustainability indices continue to contribute to the transgression of the planetary boundaries (Borland et al., 2016). Obviously, most conceptualizations of sustainable development - and some of sustainable entrepreneurship - pre-dated Rockström et al.'s (2009a, 2009b) publications on the planetary boundaries. The time has come to better understand the real impact that entrepreneurial economic activity has on our social, environmental and economic system in general and on the planetary boundaries in particular. To what extent do entrepreneurs respect or violate the boundaries of the Earth system and help to solve the environmental challenges related to these boundaries? That is, to what extent are 
sustainable enterprises themselves "living within the constraints and limits of the biophysical world" (Borland et al., 2016, p. 295)? This calls for clarification and of integrating environmental and ecological aspects in entrepreneurship in general and in sustainable entrepreneurship more specifically, in sync with the current literature (Biloslavo et al., 2018; Borland et al., 2016; Broman and Robèrt, 2017; Dyllick and Muff, 2016; Heikkurinen et al., 2016; Stål and Bonnedahl, 2016).

At the micro-level, there is apparent progress and an increased environmental awareness among individuals and companies which is assisted by industrialized and technological advancements, including social media (Biloslavo et al., 2018). In addition, progress has been made by companies in being more environmentally responsible, by consumers in gradually changing their patterns of consumption and to some extent by governments in imposing regulatory obligations (Biloslavo et al., 2018; Stål and Bonnedahl, 2016). Despite the positive directions that entrepreneurs explore, the question remains to what extent their efforts contribute to the consumption of natural resources in a way that - directly or indirectly - contributes to the transgression of the planetary boundaries. Are they aware of the externalities that their enterprises create? Do they conduct a full assessment of the potential environmental outcomes prior to developing new business opportunities?

At the macro-level, the situation seems more problematic. Collective firm actions have resulted in severe pollution and environmental degradation (Cohen and Winn, 2007), reaffirming that society still demonstrates the characteristics of a tragedy of the commons. The European National Emissions Ceilings Directive report (2019) and supportive scholarship (Biloslavo et al., 2018; Dyllick and Muff, 2016), for instance, show a decline of the natural environment as a result of the collective outcomes of individual actions. The European Environment Agency (2019) indicates in the report that emission levels are being transgressed by six EU member states, while sixteen EU member states indicate that they are not on track regarding there national emission levels in 2020. The Earth's decline is linked to the extensive use of resources for years and to the lack of adequate business frameworks and processes of responsible resourcing (Biloslavo et al., 2018; Broman and Robèrt, 2017; Dyllick and Muff, 2016; Stål and Bonnedahl, 2016). Nonetheless, it is also linked to the ongoing debate concerning more ecological sustainability vis-à-vis economic competitive advantage through technological advancements and innovation without taking into consideration the Earth's finite capacity (Biloslavo et al., 2018; Borland et al., 2016; Broman and Robèrt, 2017; Dyllick and Muff, 2016; Heikkurinen et al., 2016; Stål and Bonnedahl, 2016). Academic approaches that try to effectively connect both are limited. Existing conceptualizations, such as, e.g. eco-efficiency, the business case for sustainability, and shared value creation miss a direct reference and positioning of the organization into the core of the biosphere (Biloslavo et al., 2018; Borland et al., 2016; Broman and Robèrt, 2017; Dyllick and Muff, 2016; Heikkurinen et al., 2016; Stål and Bonnedahl, 2016). Ecological questions are still at the periphery of organizational theory (Heikkurinen et al., 2016). So far, most organizational scholars reproduce anthropocentric perspectives without addressing the ecological embeddedness of organizational activity and the dependency of the economy on ecosystems in general and the planetary boundaries in particular (Biloslavo et al., 2018; Borland et al., 2016; Broman and Robèrt, 2017; Heikkurinen et al., 2016).

Economic frameworks of competitiveness, both at the business and market level, should not operate without reference to the economy's embeddedness in and its dependency on the biophysical ecosystem (Borland et al., 2016). They should contain the "essential aspects of ecological and social systems that need to be sustained in order not to systemically undermine the capacity of nature and people now and in the future", such as the planetary boundaries (Broman and Robèrt, 2017, p. 22). Shepherd and Patzelt's (2011) definition of sustainable entrepreneurship attempts to explain "what is to be sustained in sustainable entrepreneurship?" They define, at a rather general and abstract level: (i) "nature" as "phenomena of the physical world" which includes the "earth, biodiversity and ecosystems"; (ii) "sources of life" as "a source of resources and services for the utilitarian life support of humankind" including "the environment, natural resources, and ecosystem services"; and finally (iii) "communities" as "a complex web of relationships between a set of individuals who share values, norms, meanings, history, and identity" including particularly "culture, groups, and places" (Shepherd and Patzelt, 2011, p. 139). In addition, the authors elaborate on "What is to be developed in sustainable entrepreneurship?" including, i.e. "economic gains for the actor and/or the society", "non-economic gains to individuals" (such as child survival, life expectancy, education, equity, and equal opportunity) and "non-economic gains to society" (meaning societal gains which are available to all). Despite its usefulness in distinguishing between sustainable protection and value creation, the framework of Shepherd and Patzelt (2011) - like the definition of the Brundtland Commission - leaves open the opportunity for trade-offs between the economic, environmental, and social interests without sufficiently guaranteeing the basic requirements for life on Earth. As a result, the framework fails to protect the environment in a dynamic economic and political system in ways that 'enough and as good' is left for future generations. Moreover, their contribution lacks guidance on what policies, activities and (innovative) products and processes lead to micro- and macro-economic progress, while complying fully with the demands of the planetary boundaries based on the best available knowledge. This entails that enterprises should not contribute to the transgression of the current boundaries by the industry they are part of and minimizing the risk that they will contribute to future transgressions that potentially impact the ability of future generations to meet their needs.

\subsection{Sustainable entrepreneurship and respect for the planetary boundaries}

Recently, scholars have pointed to the need of developing a framework that acknowledges and respects the planetary boundaries. Stål and Bonnedahl (2016, p. 75), demonstrate that "economic value cannot be created without some input of capital originating in nature" and recommend that a new framing is needed in sustainable entrepreneurship. However, the idea of continuous economic growth is at odds with the Earth's capacity if value creation is understood as the production and distribution of marketable goods and services comprising materials, energy and waste which deplete the Earth's "critical natural capital" beyond market demand which cannot be replaced (Stål and Bonnedahl, 2016, p. 76). Accordingly, Stål and Bonnedahl (2016, p. 79) argue, entrepreneurial opportunities can only be conceived as sustaining the Earth's critical natural capital if they are based on "circular or closed loop models". Unfortunately, despite the positive contribution of circularity to protect the Earth's critical resources, it does not necessarily and sufficiently lead to the preservation of these resources. As MuñozTorres et al. (2018) point out, there are no guarantees that "the circular economy paradigm maintains the Earth system without contributing to crossing the finite boundaries of the planet". As an example, the authors refer to the growing demand of energy to recycle materials as a result of the larger impact recycling has on energy demand in comparison to the use of virgin resources (Geissdoerfer et al., 2017). A framework should, therefore, exceed the demands for circular production, distribution and consumption 
per se, and - preferably ex-ante to developing and introducing new products, services, interventions, et cetera - assess the planetary impact of the entrepreneurial innovation, now and for future generations. Thereby the framework should focus on business activities and their environmental impact in the entire value chain and not limit itself to the performance of individual organizations.

This leads to the conclusion that the concept of 'sustainable entrepreneurship' - and the WCED definition of 'sustainable development' on which it rests - in the way it currently manifests itself, negatively impacts the ability to future generations to meet their needs. We simply do not leave "enough and as good" behind for generations to come. Our global society violates both John Locke's provisos and continues to do so as long as we do not respect the latest scientific knowledge on the severity of our transgression of the planetary boundaries, and the ways in which that transgression takes place.

\section{The way forward}

In overcoming market imperfections, entrepreneurship can play an important positive role in creating an environmentally sustainable world (Cohen and Winn, 2007; Dean and McMullen, 2007). Entrepreneurial opportunities can be seized in addressing imperfectly distributed information, flawed pricing mechanisms, externalities, or inefficiencies and add economic and environmental value for the enterprise and for society (Cohen and Winn, 2007). The larger the imperfections and the degradation of the economically viable environment, the greater the magnitude of entrepreneurial opportunities. As Dean and McMullen (2007, p. 52) argue: "[b]oth increasing evidence of substantive environmental degradation and recent market developments in renewable energy, fuel cells, green building, natural foods, carbon emissions, and other sectors suggest an increasing importance of opportunities for environmental entrepreneurship". Numerous companies contribute measurably to economic, social and/or sustainable progress without negatively influencing the environmental limits of the planet. Take the example of a rating agency that provides comprehensive and superior sustainability information. This service does not impact the planetary boundaries. The same counts for Closing the Loop, a global service provider that collects the vast amount of outdated mobile phones in Africa in order to locally retrieve valuable metals. It is turning waste into something that is of value to local employees in several African countries, the enterprise itself, its customers, and society at large. But what about the production of electric vehicles? Manufacturing these cars is, inter alia, dependent on the mining of scarce minerals like cobalt and lithium, recharging the batteries is based on energy mainly coming from fossil fuels, and the recycling of e-waste is still marginal. The Brundtland Commission would not likely qualify electric car making as an infringement of its definition of sustainable development. The car makers contribute to our needs, and by doing so they seemingly do not have a direct negative impact on the ability of future generations to meet their needs. At present, and compared to traditional cars, electric car making is even seen as an important contribution to sustainable development, while Tesla is celebrated as one of the 100 most sustainable listed companies in the world (Corporate Knights, January 22, 2019). However, the entire chain of electric automobile manufacturing, charging batteries and recycling of the cars might potentially impact the planetary boundaries, particularly if society demands a significant increase in electric car use as part of the implementation of the Paris Agreement. Therefore, it becomes relevant to re-evaluate the concepts of sustainable development and sustainable entrepreneurship in light of the dilemmas that society, consumers and entrepreneurs face when only possessing partial and sometimes partisan information.

In a recent contribution based on the concept of the planetary boundaries, Foley (2017) looks at natural ecological systems to detect how they succeed in an ever-changing environment. By mimicking nature, organizations can learn how they can best adapt to dynamic environmental challenges. Foley starts by recognizing that the data about the state of the planet do not tell us what to do. Some people will sound the alarm bell when confronted with transgressions of the planetary boundaries, but others detect new opportunities for mankind. They take an interest in the "extraordinary levels of human ingenuity" (Foley, 2017, p. 252). Research suggests that sustainable entrepreneurship finds itself on the side of those that see the opportunities (Cohen and Winn, 2007; Dean and McMullen, 2007; York and Venkataraman, 2010). Entrepreneurship shows itself as innovation - instead of conservation through which environmental degradation can be addressed and reduced (York and Venkataraman, 2010). Foley (2017) might concur with this view as he believes that innovation and diversification are essential elements of an adaptive natural ecological system, thereby making the system more robust in the face of changing conditions. This is the first guidance that natural ecological systems provide (Foley, 2017, p. 252). That nature uses the sun as its primary source of energy is not surprising and the second guidance for a society that is dependent on fossil fuels. The move towards more sustainable energy is desirable, but insufficient to provide society with the energy required to reproduce its current social and economic habitat. A complete turn towards renewables is worth striving for and provides opportunities for sustainable entrepreneurship but is not feasible at present. The guidance to respect and to promote diversity and to be powered by the sun is meaningful, but it does not address the potential transgression of the planetary boundaries. Foley (2017) provides additional guidance, based on previous work by the economist Herman Daly (2007, p. 14) and, interestingly enough, on the proviso provided by Locke. Systems which respect the planetary boundaries:

\section{- Do not consume resources faster than they are regenerated by the environment - thereby leaving enough and as good for future generations; and \\ - Do not produce wastes, especially those that disrupt the envi- ronment and the climate system, faster than they are assimi- lated or removed by the environment.}

Mimicking nature, entrepreneurial activity needs to be studied in individual enterprises and at a system level to avoid externalities up or down the value chain, and to create resilience and transformation in a complex world (Porter and Derry, 2012). Looking at value chains, it is the cumulative effect on the boundaries that is created by enterprises and the other relevant nodes (Bolwig et al., 2010) in the value chain that matters. Regarding the manufacturing and use of electric automobiles, it is important to assess the contribution of all the nodes in the value chain to the potential violation of the planetary boundaries. The cars themselves may be free of emitting $\mathrm{CO}_{2}$, recharging the batteries often uses fossil fuels. Also, the mining of lithium by mining giant BHP requires approximately 1000 times as much fresh water on a daily basis as the amount that is available for humans and their livestock on the Chilean salt plateaus (Bloomberg, 2019), thereby threatening the biodiversity in the area.

\subsection{Redefining sustainable development and sustainable entrepreneurship}

If we define sustainable development, in line with Griggs et al. (2013, p. 306), as a development that "meets the needs of the 
present, complies with the planetary boundaries and does not compromise the ability of future generations to meet their needs without transgressing these same planetary boundaries", it puts the burden on the public and the private sector to prevent any material contribution to the transgression of the planetary boundaries. Since the electric carmakers have a negative impact on some of the boundaries, they are no longer considered as 'sustainable'. Recognition as sustainable enterprises only follows their impact on the planetary boundaries, including the use of water in mining lithium, to the extent that they do no longer consume resources to a larger extent than they are regenerated by nature. Consequently, and inspired by Dean and McMullen (2007, p. 58), we define sustainable entrepreneurship as the process of discovering, evaluating, and exploiting opportunities, which are economically, environmentally, planetarily, and socially relevant and present themselves in market failures which detract from sustainability in general and the planetary boundaries in particular. This requires entrepreneurship in general and sustainable entrepreneurship in particular to assess, adopt, and report on compliance with the two provisos provided by Foley (2017) regarding waste and the use of resources - aiming to reduce potential transgressions of the planetary boundaries. Therefore, companies in the extractives industries, in petrochemicals, utilities and wholesale power, but also in the financial services industry are suddenly in violation of the principle of sustainable development. This applies to all enterprises included in the many sustainability indices - most notably the Dow Jones Sustainability Index. Leaders in industry sectors as diverse as aerospace, agriculture, automobiles, chemicals, construction and engineering, energy, metals and mining, transportation, et cetera, contribute to the transgression of the planetary boundaries - and therefore disqualify as being sustainable. This potentially affects one quarter of the Global 100 Most Sustainable Corporations in the World index (Corporate Knights, 2019). The most sustainable enterprises according to GlobeScan (2019) - like Interface, Natura Brasil, Patagonia and IKEA ${ }^{6}$ - demonstrate, however, that it is possible to respect the planetary boundaries while creating paradigmatic companies. Hereafter, Interface is presented as an illustrative case of a company that operationalizes Foley's guidance. ${ }^{7}$

\subsection{The case of interface}

Interface was founded in 1973 by Ray Anderson to produce and sell modular carpet tiles, luxury vinyl tile and rubber flooring. In 1993, the founder got inspired by Paul Hawken's book The Ecology of Commerce (1993) in which the author argues that the market and the state are capable of solving the challenges of the planet. Hawken (1993) proposes eight objectives of which two are important for meeting the needs of the planet. The first is to reduce absolute consumption of energy and natural resources in the North by 80 percent before 2040 . The second is to exceed sustainability by restoring degraded habitats and ecosystems to their fullest biological capacity. That means that efforts have to go beyond cleaning up the mess that we make. Limiting ourselves to a clean-up is like celebrating cancer treatment that cures a tumor that should not have been there in the first place (Hawken, 1993). Both objectives inspired Anderson in 1994 to adopt Mission Zero. It challenged the company to, inter alia, eliminate waste, emit zero molecular and

\footnotetext{
${ }^{6}$ The GlobeScan index is based on the assessment of leading sustainability experts. Interface, Natura Brasil, Patagonia and IKEA belong to the top five of the most sustainable companies in the world. Two of them also received the UN Champions of the Earth award. https://www.unenvironment.org/championsofearth/.

7 The case of Interface is part of a larger study conducted by one of the authors that looks into the other-oriented behaviour of companies in The Netherlands.
}

toxic waste, switch to renewable energy, redesign processes and products so resources can be reused, use resource-efficient transportation of people and products, sensitize stakeholders, and focus on the delivery of service and value instead of material, by 2020 . To achieve these objectives Interface started collaborating with The Natural Step (Naturalstep.org) and to Biomimicry 3.8 (Biomimicry. net). With the support of both organizations it developed an approach that, over time, resulted in replacing latex with recycled $\mathrm{PVB}^{8}$ in precoats, or in using discarded fishing nets for its fibers through its Net-Works ${ }^{\circledR}$ program. Also, production facilities have made significant progress in the use of renewable energy. In 2018, the company announced that all products were carbon neutral across the entire product lifecycle.

Already in 2016, the company announced that its new mission after 2020 would become Climate Take Back, aiming to go from restoration to regeneration. One of the objectives is to run its industrial plants as ecosystems. Also, through 'Love Carbon' Interface works with materials that absorb waste carbon or sequester carbon to make new products. Finally, through its 'Lead the Industrial Rerevolution' the company works together with industry partners. Part of this program and aligned with Foley's (2017) idea to mimic nature, is Interface's biophilic design approach. ${ }^{9}$ Together with the British architect Oliver Heath the company created a 'positive space' in a school for children with autism in Hackney (London), based on a child's innate attraction to nature (Heath, 2019). An unused space in the school was turned into a safe and recuperative area. Depending on their mood, the space allows children to reach out and play with others, but also to hide away from others in one of the many alcoves and cubes it is filled with. These initiatives, taken together, express a concern for the Earth's biosphere, and promote innovation in the company and the value chain that respects the planetary boundaries.

Taken everything together, Interface, in its business strategies, its design and production processes, its marketing, sales and aftersales, its communication, and its reporting:

- Assesses its potential environmental impact on current and
future generations both ex-ante and ex-post;
- Respects the planetary boundaries; and
- Balances the constituent elements of sustainable development,
being economic prosperity, environmental protection and hu-
man development.

In addition, the company respects Locke and Foley's additional provisos to not consume resources faster than they are regenerated by the environment - thereby leaving enough and as good for future generations - and to not produce wastes faster than they are assimilated or removed by the environment. For a company that is listed on the NASDAQ, this is a remarkable achievement.

\section{Discussion and conclusion}

Sustainable entrepreneurship plays an important role in overcoming market imperfections, by seizing the opportunities for simultaneously balancing "economic health, social equity and environmental resilience" (Cohen and Winn, 2007, p. 34). Through the innovations that it designs, manufactures and brings to the

\footnotetext{
8 Polyvinyl butyral (or PVB) is a resin with a strong cohesiveness, optical clarity, adhering easily to many surfaces.

9 Literally, the term means 'friend of life' and was used by E.O. Wilson's Biophilia (1984) to refer to the innate tendency to focus on life and lifelike processes. Elsewhere, Wilson (1994) describes biophilia as an inborn affinity that human beings have for other forms of life.
} 
market, sustainable entrepreneurship can contribute to the preservation of the Earth system and to the development of mankind. It creates progress through ideas and practices of innovative ecocentric business frameworks, models and processes which are deeply embedded in the Earth's biophysical existence. Sustainable entrepreneurship aims to create value in ways that correct the often-unsustainable production and distribution of marketable goods and services which deplete the Earth's finite resources. Many sustainable entrepreneurs want to prevent further degradation of the ecological system and correct the imperfections in the market economy, both individually and collectively by changing the rules of the economic game (Dean and McMullen, 2007; Pacheco et al., 2010; Pinkse and Groot, 2015). Nevertheless, much of the economic growth that is created at present - even by sustainable entrepreneurs - ignores the planetary boundaries and reflects the decline of critical natural and social capital. Hence, compliance with the planetary boundaries and being open about the positive and negative entrepreneurial impact on the planetary boundaries becomes a sine qua non to development and a prerequisite for the Earth's future existence for both sustainable and non-sustainable businesses. For this reason, society not only needs (sustainable) entrepreneurs who contribute to reversing the tragedy of the commons, but who also redefine sustainable development in ways that acknowledge the planetary boundaries as strict limits to economic progress, environmental quality and human development. Just like John Locke (1689: section 35 and 36), claimed that "there is land enough in the world to suffice twice as many people as there are", the Brundtland Commission was too lenient. It did not set strict and qualified limits to the economic growth - no matter how important that same growth is to preserve nature and develop human society.

As a result, we suggest redefining both sustainable development and sustainable entrepreneurship. Sustainable development can best be seen as development that meets the needs of the present, complies with the planetary boundaries and does not compromise the ability of future generations to meet their own needs without transgressing these same planetary boundaries. The value of sustainable entrepreneurship lies in the introduction of new solutions that adds new 'livestock' to the commons in ways that do not harm the interest of others. It might even improve the situation of those who are the worst off (cf. Rawls, 1999) - both now and in the future. New products, services and interventions can positively contribute to sustainable development, while at the same time curbing the trend of negative externalities, as long as it complies with dynamic planetary boundaries. This requires a redefinition of sustainable entrepreneurship as the process of discovering, evaluating, and exploiting opportunities, which are economically, environmentally, planetarily, and socially relevant and present themselves in market failures which detract from sustainability in general and the planetary boundaries in particular.

In taking its responsibility sustainable entrepreneurship needs the support of governments, investors, civil society organizations, and consumers as sustainable entrepreneurs cannot succeed in a world that fails. Acknowledging, understanding and embracing the Earth's finite capacity should be manifested in all aspects of social and economic life. Taking the planetary limitations into account in a timely and adequate fashion, is therefore an indispensable condition for true sustainable development and consequently for true sustainable entrepreneurship. The shining examples of companies like Interface, Patagonia, and Nature demonstrate that entrepreneurial businesses can create economic, societal and ecological value while respecting the planetary boundaries and encourage others to do the same. These enterprises explore opportunities that result in transformations towards a more sustainable economy. They are the first movers and set an example for their respective industries. What is even more important is that they are actively seeking collaboration with others to influence the conditions under which companies create economic growth (cf. Dean and McMullen, 2007; Pacheco et al., 2010; Pinkse and Groot, 2015). Initiatives like Interface's 'Lead the Industrial Re-revolution' is a case in point.

\subsection{Our contribution}

This article aims to contribute to a dialogue on the meaning of sustainable development and its implementation in the business community. We have argued that 'sustainable development' under the current economic conditions carries in it the risk of becoming an oxymoron. The phrase becomes meaningless if it insufficiently addresses the environmental limits of the planet (Biloslavo et al., 2018; Borland et al., 2016; Broman and Robèrt, 2017; Dyllick and Muff, 2016; Heikkurinen et al., 2016; Patzelt and Shepherd, 2011; Salmivaara and Kibler, 2020; Shepherd and Patzelt, 2011; Stål and Bonnedahl, 2016). We have argued that the authoritative definition of sustainable development that was formulated in 1987 by the Brundtland Commission requires reformulation in light of increasing transgressions of the planetary boundaries. It is only by respecting these boundaries that business meets a necessary condition of sustainable development by leaving future generations in a position that they can meet their needs. In addition, we recognize the potential of sustainable entrepreneurship to make a significant contribution to creating a more sustainable economy. Sustainable entrepreneurship helps to innovate business by e.g. reducing waste, creating more circular business processes, using renewable energy, et cetera. It introduces new products and services that respect the planetary boundaries and helps to control and minimize and the effects businesses have on society and on the planet. Apart from other forms of collective action (Yoffie, 1988; Pacheco et al., 2010; Pinkse and Groot, 2015), the call for sustainable development requires, inter alia, 'analytic deliberations', defined as a "[w]ellstructured dialogue involving scientists, resource users, and interested publics, and informed by analysis of key information about environmental and human-environment systems" (Dietz et al., 2003). As the authors point out, these deliberations result in improved information and trust in that information, which is essential for information to be used effectively. In a society where companies increasingly claim that they contribute to sustainable development, analytic deliberations can be an effective instrument against greenwashing. The need for analytic deliberations is reinforced in light of the current framing of the debate on sustainable development and sustainable entrepreneurship in a political context (Pinkse and Groot, 2015; Salmivaara and Kibler, 2020). Business and governments often show a lack of attention for the planetary boundaries and measures needed to protect these boundaries. It is precisely at this point that sustainable entrepreneurship can make a significant contribution to the deliberations by demonstrating how respecting the planetary boundaries and creating new products and services can be in sync with each other.

\subsection{Suggestions for further research}

Beyond developing a definition for sustainable development which is in line with the planetary boundaries, this article demonstrates that future research is needed on the way economic ideas and concepts, like the conceptual understanding of growth and value, evolve over time. Looking at the planet's finite resources reconsidering these ideas and concepts is necessary. Sustainable entrepreneurship can pave the way in which business safeguards the planet's sustenance and hence mankind's future existence and development. Future research can identify which types of entrepreneurial opportunities are relevant for sustainable 
entrepreneurship embedded into policy frameworks that respect the planetary boundaries. In addition, future research can elaborate eco-centric innovative business models, business frameworks, and operational and governance processes that include the biosphere in their core. Finally, developing new institutions or changing existing institutions for sustainable development through sustainable entrepreneurship, is imminently required. In line with, inter alia, Dean and McMullen (2007), Pacheco et al. (2010), and Pinkse and Groot (2015), this article questions the validity of the existing, unsustainable institutional arrangements and endorses the creation of new norms and institutions via a process of institutional change. In particular, sustainable entrepreneurship may influence institutional change by shaping and changing existing formal institutions and by directly influencing societal and political actors and/or policy and regulatory/law making towards sustainable entrepreneurship and respect for the planetary boundaries.

\section{Credit author statement}

Harry Hummels: Conception and design of study, Analysis and/ or interpretation, Drafting the manuscript, Revising the manuscript critically, Approval of the manuscript to be published. Aikaterini Argyrou: Conception and design of study, Analysis and/or interpretation, Drafting the manuscript, Revising the manuscript critically, Approval of the manuscript to be published.

\section{Ethical approval}

This article does not contain any studies with human participants or animals performed by the authors.

\section{Declaration of competing interest}

The authors declare that they have no known competing financial interests or personal relationships that could have appeared to influence the work reported in this paper.

\section{Acknowledgements}

The authors declare that they have not included an Acknowledgements as they have not received substantial contributions from non-authors.

\section{References}

American Business Roundtable, 2019. Business roundtable redefines the purpose of a corporation to promote 'an economy that serves all Americans'. https://www. businessroundtable.org/business-roundtable-redefines-the-purpose-of-acorporation-to-promote-an-economy-that-serves-all-americans (accessed 18 June 2020).

Ardichvili, A., Cardozo, R., Ray, S., 2003. A theory of entrepreneurial opportunity identification and development. J. Bus. Ventur. 18 (1), 105-123. https://doi.org/ 10.1016/S0883-9026(01)00068-4.

Austin, J., Stevenson, H., Wei-Skillern, J., 2006. Social and commercial entrepreneurship: same, different, or both? Enterpren. Theor. Pract. 30, 1-22. https:// doi.org/10.1111/j.1540-6520.2006.00107.x.

Baumol, W.J., 1990. Entrepreneurship: productive, unproductive, and destructive. J. Polit. Econ. 98 (5), 893-921. https://www.jstor.org/stable/2937617.

Belz, F.M., Binder, J.K., 2017. Sustainable entrepreneurship: a convergent process model: sustainable entrepreneurship: a convergent process model. Bus. Strat. Environ. 26 (1), 1-17. https://doi.org/10.1002/bse.1887.

Biloslavo, R., Bagnoli, C., Edgar, D., 2018. An eco-critical perspective on business models: the value triangle as an approach to closing the sustainability gap. J. Clean. Prod. 174, 746-762. https://doi.org/10.1016/j.jclepro.2017.10.281.

Bloomberg, 2019. Saving the planet with electric cars means strangling this desert. https://www.bloomberg.com/news/features/2019-06-11/saving-the-planetwith-electric-cars-means-strangling-this-desert (accessed 24 January 2020).

Bolwig, S., Ponte, S., Du, T.A., Riisgaard, L., Halberg, N., 2010. Integrating poverty and environmental concerns into value-chain analysis: a conceptual framework. Dev. Pol. Rev. 28 (20), 173-194. https://doi.org/10.1111/j.14677679.2010.00480.x.
Borland, H., Ambrosini, V., Lindgreen, A., Vanhamme, J., 2016. Building theory at the intersection of ecological sustainability and strategic management. J. Bus. Ethics 135 (2), 293-307. https://doi.org/10.1007/s10551-014-2471-6.

Broman, G.I., Robèrt, K.-H., 2017. A framework for strategic sustainable development. J. Clean. Prod. 140, 17-31. https://doi.org/10.1016/j.jclepro.2015.10.121.

Brown, B.J., Hanson, M.E., Liverman, D.M., Merideth, R.W., 1987. Global sustainability: toward definition. Environmental management: an international journal for decision makers. Scientists and Environmental Auditors 11 (6), 713-719. https://doi.org/10.1007/BF01867238.

Carter, M., 2006. Entrepreneurship and marketing. In: Casson, M., Yeung, B., Basu, A., Wadeson, N. (Eds.), The Oxford Handbook of Entrepreneurship. Oxford University Press, Oxford, pp. 115-116.

Cohen, B., Winn, M.I., 2007. Market imperfections, opportunity and sustainable entrepreneurship. J. Bus. Ventur. 22 (1), 29-49. https://doi.org/10.1016/ j.jbusvent.2004.12.001.

Constanza, R., Patten, B.C., 1995. Defining and predicting sustainability. Ecol. Econ. 15, 193-196. https://doi.org/10.1016/0921-8009(95)00048-8.

Corporate Knights, 2019. The Global 100 most sustainable companies in the world https://www.corporateknights.com/reports/2019-global-100/2019-global-100results-15481153/ (accessed 24 January 2020).

Crals, E., Vereeck, L., 2004. SME's and sustainable entrepreneurship: theory and practice. In: Philips, C. (Ed.), Environmental Justice and Global Citizenship. Interdisciplinary Press, Oxford, pp. 37-46.

Daly, H.E., 1973. Toward a steady-state economy. W.H. Freeman, San Francisco.

Daly, H.E., 2007. Ecological Economics and Sustainable Development, Selected Essays of Herman E. Daly. Edward Elgar Publishing Limited, Cheltenham, UK.

Davies, I.A., Chambers, L., 2018. Integrating hybridity and business model theory in sustainable entrepreneurship. Journal of Cleaner Production 177, 378-386. https://doi.org/10.1016/j.jclepro.2017.12.196.

Dean, T.J., McMullen, J.S., 2007. Toward a theory of sustainable entrepreneurship: reducing environmental degradation through entrepreneurial action. J. Bus. Ventur. 22 (1), 50-76. https://doi.org/10.1016/j.jbusvent.2005.09.003.

Dietz, T., Ostrom, E., Stern, P., 2003. The struggle to govern the commons. Science 302 (5652), 1907-1912. https://doi.org/10.1126/science.1091015.

Dyllick, T., Muff, K., 2016. Clarifying the meaning of sustainable business: introducing a typology from business-as-usual to true business sustainability. Organ. Environ. 29 (2), 156-174. https://doi.org/10.1177/1086026615575176.

Ehrlich, P., 1968. The Population Bomb. Ballantine Books, New York.

Eisenmann, R.T., 2013. Entrepreneurship: a working definition. Harvard business review. https://hbr.org/2013/01/what-is-entrepreneurship (accessed 24 January 2020).

Emerson, J., 2003. The blended value proposition: integrating social and financial returns. Calif. Manag. Rev. 45 (4), 35-51. https://doi.org/10.2307/41166187.

European Environment Agency, 2019. NEC Directive Reporting Status 2019 (accessed 24 January 2020). https://www.eea.europa.eu/themes/air/nationalemission-ceilings/nec-directive-reporting-status-2019.

Foley, J., 2017. Living by the lessons of the planet. Science 356 (6335), 251-252 https://doi.org/10.1126/science.aal4863.

Gast, J., Gundolf, K., Cesinger, B., 2017. Doing business in a green way: A systematic review of the ecological sustainability entrepreneurship literature and future research directions. Journal of Cleaner Production 147, 44-56. https://doi.org/ 10.1016/j.jclepro.2017.01.065.

Geissdoerfer, M., Savaget, P., Bocken, N.M., Hultink, E.J., 2017. The Circular Economy: a new sustainability paradigm? J. Clean. Prod. 143, 757-768. https://doi.org/ 10.1016/j.jclepro.2016.12.048.

GlobeScan, 2019. The 2019 Sustainability Leaders. https://globescan.com/wpcontent/uploads/2019/07/GlobeScan-SustainAbility-Leaders-Survey-2019Report.pdf (accessed 24 January 2020).

Griggs, D., Stafford-Smith, M., Rockström, J., Öhman, M.C., Gaffney, O., Glaser, G., Kanie, N., Noble, I., Steffen, W., Shyamsundar, P., 2014. An integrated framework for sustainable development goals. Ecol. Soc. $19(4,49)$ https://doi.org/10.5751/ ES-07082-190449.

Griggs, D., Stafford-Smith, M., Gaffney, O., Rockström, J., Öhman, M.C., Shyamsundar, P., Steffen, W., Glaser, G., Kanie, N., Noble, I., 2013. Policy: sustainable development goals for people and planet. Nature 495, 305-307. https://doi.org/10.1038/495305a.

Hall, J.K., Daneke, G.A., Lenox, M.J., 2010. Sustainable development and entrepreneurship: past contributions and future directions. J. Bus. Ventur. 25 (5), 439-448. https://doi.org/10.1016/j.jbusvent.2010.01.002.

Hardin, G., 1968. The tragedy of the commons. Science 162 (3859), 1243-1248. https://doi.org/10.1126/science.162.3859.1243.

Hart, S.L., Milstein, M.B., 2003. Creating sustainable value. Acad. Manag. Perspect. 17 (2), 56-67. https://doi.org/10.5465/ame.2003.10025194.

Hawken, P., 1993. The Ecology of Commerce: A Declaration of Sustainability. HarperBusiness, New York.

Heath, O., 2019. The Garden school, Hackney. Interface. https://www.interface.com/ EU/en-GB/campaign/positive-spaces/hackney-garden-school-en_GB (accessed 24 January 2020).

Heikkurinen, P., Rinkinen, J., Jarvensivu, T., Wilen, K., Ruuska, T., 2016. Organising in the Anthropocene: an ontological outline for ecocentric theorising. J. Clean. Prod. 113, 705-714. https://doi.org/10.1016/j.jclepro.2015.12.016.

Hockerts, K., Wüstenhagen, R., 2010. Greening Goliaths versus emerging Davids theorizing about the role of incumbents and new entrants in sustainable entrepreneurship. J. Bus. Ventur. 25 (5), 481-492. https://doi.org/10.1016/ j.jbusvent.2009.07.005. 
Holdren, J.P., Daily, G.C., Ehrlich, P.R., 1995. The Meaning of Sustainability: Biogeophysical Aspects. The World Bank. http://www.jayhanson.org/page113.htm (accessed 24 January 2020).

Horne, J., Recker, M., Kratzer, J., Michelfelder, I., Jay, J., Kratzer, J., 2020. Exploring entrepreneurship related to the sustainable development goals - mapping new venture activities with semi-automated content analysis. Journal of Cleaner Production 242,1-11. https://doi.org/10.1016/j.jclepro.2019.118052.

International Union for Conservation of Nature, 1991. Caring for the earth: a strategy for sustainable living. https://portals.iucn.org/library/efiles/ documents/cfe-003.pdf (accessed 24 January 2020).

Jaramillo, F., Destouni, G., 2015. Comment on "Planetary boundaries: guiding human development on a changing planet". Science 348 (6240), 1217. https:// doi.org/10.1126/science.aaa9629.

Katsikis, I.N., Kyrgidou, L., 2007. The concept of sustainable entrepreneurship: a conceptual framework and empirical analysis. Acad. Manag. Proc. 1, 1-6. https://doi.org/10.5465/ambpp.2007.26530537.

Kuckertz, A., Wagner, M., 2010. The influence of sustainability orientation on entrepreneurial intentions Investigating the role of business experience. J. Bus. Ventur. 25 (5), 524-539. https://doi.org/10.1016/j.jbusvent.2009.09.001.

Lankoski, L., 2016. Alternative conceptions of sustainability in a business context. J. Clean. Prod. 139, 847-857. https://doi.org/10.1016/j.jclepro.2016.08.087.

Lans, T., Blok, V., Wesselink, R., 2014. Learning apart and together: towards an integrated competence framework for sustainable entrepreneurship in highe education. J. Clean. Prod. 62, 37-47. https://doi.org/10.1016 j.jclepro.2013.03.036.

Liu, J., Xu, Z., Chung, M.G., Sun, J., Li, S., Hull, V., Godfray, H.C.J., Tilman, D., Gleick, P. Hoff, H., Hoff, H., Pahl-Wostl, C., Sun, J., 2018. Nexus approaches to global sustainable development. Nature Sust. 1 (9), 466-476. https://doi.org/10.1038/ s41893-018-0135-8.

Locke, J., 1689. Two Treatises of Government. London, J. Locke, UK.

Lovelock, J.E., Margulis, L., 1974. Atmospheric homeostasis by and for the biosphere: the gaia hypothesis. Tellus 26 (1-2), 2-10. https://doi.org/10.1111/j.2153 3490.1974.tb01946.x.

Malthus, T.R., 1826. An Essay on the Principle of Population. John Murray, UK: London.

Meadows, D.H., Randers, J., Meadows, D.L., 1972. Limits to Growth: the 30-year Update. Earthscan. UK: London.

Mebratu, D., 1998. Sustainability and sustainable development: historical and conceptual review. Environ. Impact Assess. Rev. 18 (6), 493-520. https:// doi.org/10.1016/S0195-9255(98)00019-5.

Muñoz, P., Cohen, B., 2018. Sustainable entrepreneurship research: taking stock and looking ahead. Bus. Strat. Environ. 27 (3), 300-322. https://doi.org/10.1002/ bse.2000.

Muñoz-Torres, M.J., Fernández-Izquierdo, M., Rivera-Lirio, J.M., Ferrero-Ferrero, I. Escrig-Olmedo, E., Gisbert-Navarro, J.V., Marullo, M.C., 2018. An assessment too to integrate sustainability principles into the global supply chain. Sustainability 10 (2), 535. https://doi.org/10.3390/su10020535.

O'Neill, G.D., Hershauer, J.C., Golden, J.S., 2006. The cultural context of sustainability entrepreneurship. Greener Manag. Int. 55, 33-46. https://www.jstor.org/stable/ greemanainte.55.33 (accessed June 2020)

Pacheco, D.F., Dean, T.J., Payne, D.S., 2010. Escaping the green prison: entrepreneurship and the creation of opportunities for sustainable development. J. Bus. Ventur. 25 (5), 464-480. https://doi.org/10.1016/j.jbusvent.2009.07.006.

Parrish, B.D., Foxon, T.J., 2006. Sustainability entrepreneurship and equitable transitions to a low-carbon economy. Greener Manag. Int. 55, 47-62. https://www. jstor.org/stable/greemanainte.55.47 (accessed June 2020).

Pater, L.R., Cristea, S.L., 2016. Systemic definitions of sustainability, durability and longevity. Procedia - Social and Behavioral Sciences 221, 362-371. https:// doi.org/10.1016/j.sbspro.2016.05.126.

Patzelt, H., Shepherd, D.A., 2011. Recognizing opportunities for sustainable development. Enterpren. Theor. Pract. 35 (4), 631-652. https://doi.org/10.1111 j.1540-6520.2010.00386.x.

Pinkse, J., Groot, K., 2015. Sustainable entrepreneurship and corporate political activity: overcoming market barriers in the clean energy sector. Enterpren. Theor. Pract. 39 (3), 633-654. https://doi.org/10.1111/etap.12055.

Porter, T., Derry, R., 2012. Sustainability and business in a complex world. Bus. Soc. Rev. 117 (1), 33-53. https://doi.org/10.1111/j.1467-8594.2012.00398.x.

Rawls, J., 1999. A Theory of Justice. Oxford University Press, UK: Oxford.

Redclift, M., 2005. Sustainable development (1987-2005): an oxymoron comes of age. Sustain. Dev. 13 (4), 212-227. https://doi.org/10.1002/sd.28.

Reid, W.V., Chen, D., Goldfarb, L., Hackmann, H., Lee, Y.T., Mokhele, K., Ostrom, E. Raivio, K., Rockström, J., Schellnhuber, H.J., Whyte, A., 2010. Earth system science for global sustainability: grand challenges. Science 330 (6006), 916. https://doi.org/10.1126/science.1196263.

Rockströ, m, J., Steffen, W., Noone, K., Persson, A., Chapin, F.S., Lambin, E., Lenton, T.M., Scheffer, M., Folke, C., Schellnhuber, H., Nykvist, B., de Wit, C.A Hughes, T., van der Leeuw, S., Rodhe, H., Sörlin, S., Snyder, P.K., Costanza, R., Svedin, U., Falkenmark, M., Karlberg, L., Corell, R.W., Fabry, V.J., Hansen, J. Walker, B., Liverman, D., Richardson, K., Crutzen, P., Foley, J., 2009a. Planetary boundaries: exploring the safe operating space for humanity. Ecol. Soc. 14
(2,32). http://www.ecologyandsociety.org/vol14/iss2/art32/ (accessed June 2020)

Rockströ, m, J., Steffen, W., Noone, K., Persson, A., Chapin, F.S., Lambin, E.F., Lenton, T.M., Scheffner, M., Folke, C., Schellnhuber, H.J., Nykvist, B., de Witt, C.A., Hughes, T., van der Leeuw, S., Rodhe, H., Sörlin, S., Snyder, P.K., Costanza, R., Svedin, U., Falkenmark, M., Karlberg, L., Corell, R.W., Fabry, V.J., Hansen, J., Walker, B., Liverman, D., Richardson, K., Crutzen, P., Foley, J., 2009b. A safe operating space for humanity. Nature 461, 472-475. https://doi.org/10.1038/ 461472a.

Sachs, J., 2004. Sustainable development. Editorial. Science 304 (5671), 649. https:// doi.org/10.1126/science.304.5671.649.

Salmivaara, V., Kibler, E., 2020. "Rhetoric mix" of argumentations: how policy rhetoric conveys meaning of entrepreneurship for sustainable development. Enterpren. Theor. Pract. 44 (4), 700-732. https://doi.org/10.1177/ 1042258719845345.

Santos, F.M., 2012. A positive theory of social entrepreneurship. Journal of Business Ethics 111, 335-351. https://doi.org/10.1007/s10551-012-1413-4.

Sarasvathy, S.D., 2001. Causation and effectuation: toward a theoretical shift from economic inevitability to entrepreneurial contingency. Acad. Manag. Rev. 26 (2), 243-263. https://doi.org/10.5465/amr.2001.4378020.

Schaltegger, S., Wagner, M., 2011. Sustainable entrepreneurship and sustainability innovation: categories and interactions. Bus. Strat. Environ. 20 (4), 222-237. https://doi.org/10.1002/bse.682.

Schumpeter, J., 1934. The Theory of Economic Development. Harvard University Press, MA: Cambridge.

Shearman, R., 1990. The meaning and ethics of sustainability. Environmental management: an international journal for decision makers,. Scientists and Environmental Auditors 14 (1), 1-8. https://doi.org/10.1007/BF02394014.

Shepherd, D.A., Patzelt, H., 2011. The new field of sustainable entrepreneurship: studying entrepreneurial action linking "what is to Be sustained" with "what is to Be developed". Enterpren. Theor. Pract. 35 (1), 137-163. https://doi.org/ 10.1111/j.1540-6520.2010.00426.x.

Stal, H.I., Bonnedahl, K., 2016. Conceptualizing strong sustainable entrepreneurship. Small Enterprise Research 23 (1), 73-84. https://doi.org/10.1080/ 13215906.2016.1188718.

Steffen, W., Richardson, K., Rockström, J., Cornell, S.E., Fetzer, I., Bennett, E.M., Biggs, R., Carpenter, S.R., de Vries, W., de Wit, C.A., Folke, C., Gerten, D., Heinke, J., Mace, G.M., Persson, L.M., Ramanathan, V., Reyers, B., Sörlin, S., 2015. Planetary boundaries: guiding human development on a changing planet. Science 347 (6223). https://doi.org/10.1126/science.1259855.

Stevenson, H.H., Roberts, M., Grousbeck, H.I., 1989. New Business Ventures and the Entrepreneur. Irwin/McGraw-Hill, Boston.

Strivers, R., 1976. The Sustainable Society: Ethics and Economic Growth. Westminster Press, Philadelphia.

Teran-Yepez, E., Marin-Carrillo, G.M., Casado-Belmonte, M.P., CapobiancoUriarte, M.M., 2020. Sustainable entrepreneurship: Review of its evolution and new trends. Journal of Cleaner Production 252, 1-21. https://doi.org/10.1016/j. jclepro.2019.119742.

Thompson, N., Kiefer, K., York, J.G., 2011. Distinctions not dichotomies: exploring social, sustainable, and environmental entrepreneurship. In: Lumpkin, G.T. Katz, J.A. (Eds.), Social and Sustainable Entrepreneurship. Bingley: Emerald Books, pp. 201-229.

Tilley, F., Young, W., 2006. Sustainability entrepreneurs: could they Be the true wealth generators of the future? Greener Manag. Int. 55, 79-92. https://www. jstor.org/stable/greemanainte.55.79 (accessed June 2020).

Venkataraman, S., 1997. The Distinctive Domain of Entrepreneurship Research: an Editor's Perspective. In: Katz, J., Brockhaus, R. (Eds.), Advances in Entrepreneurship, Firm Emergence, and Growth. JAI Press, Connecticut: Greenwich, pp. $119-138$.

Walker, B., Galaz, V., Folke, C., Maler, K.-G., Barrett, S., Polasky, S., Engstrom, G., De Zeeuw, A., Ackerman, F., Arrow, K., Carpenter, S., Chopra, K., Daily, G., Ehrlich, P., Hughes, T., Kautsky, N., Levin, S., Shogren, J., Vincent, J., Xepapadeas, T., 2009. Looming global-scale failures and missing institutions. Science 325 (5946), 1345-1346. https://doi.org/10.1126/science.1175325.

White, M.A., 2013. Sustainability: I know it when I see it. Ecol. Econ. 86, 213-217. https://doi.org/10.2307/797245.

Wilson, E.O., 1984. Biophilia. Harvard University Press, MA: Cambridge.

Wilson, E.O., 1994. Naturalist, Shearwater Book, DC: Washington.

World Commission on Environment and Development [WCED], 1987. Our Common Future. Adopted by the United Nations General Assembly. A/42/427. Oxford University Press, Oxford.

Yoffie, D.B., 1988. How an industry builds political advantage. Harv. Bus. Rev. 66 (3), 82-89. https://hbr.org/1988/05/how-an-industry-builds-political-advantage (accessed June 2020).

York, J.G., Venkataraman, S., 2010. The entrepreneur-environment nexus: uncertainty, innovation, and allocation. J. Bus. Ventur. 25 (5), 449-463. https:// doi.org/10.1016/j.jbusvent.2009.07.007.

Zahra, S.A., Rawhouser, H.N., Bhawe, N., Neubaum, D.O., Hayton, J.C., 2008. Globalization of social entrepreneurship opportunities. Strategic Entrepreneurship Journal 2 (2), 117-131. https://doi.org/10.1002/sej.43. 